\title{
MISCELLANEA
}

\section{Some Recent Inquiries and Current Problems in the Social Organization of Industry}

\section{H. ALLCORN}

\section{From the Department of Social Anthropology, University of Manchester}

In industry changes in the methods and organization of work as a rule do not provide all the benefits expected of them. Some have unanticipated social and psychological repercussions, and thus the advantages of technological changes are frequently offset by social forces which the changes themselves have introduced. Although these forces are not always well understood, some encouraging progress has been made recently in sociology.

Two main types of inquiry contribute to our present knowledge of social process and structure. First, there is the kind of inquiry which Elton Mayo (1949) and his colleagues (especially Roethlisberger and Dickson, 1939; Roethlisberger, 1942) carried out at the Hawthorne Plant of Western Electric and addressed to the most readily observable forms of social relationship. Secondly, there are studies which seek to use a series of observed events as indices of processes which, initially at least, cannot be directly observed. A good example of the latter is the Acton Society Trust's recent publication Size and Morale.*

This report, which is "essentially a sample of work in progress" draws upon information from the coal industry, from a large industrial concern controlling nearly 100 separate undertakings, and from a commercial concern with 230 retail stores. It deals mainly with the associations to be found between rates of attendance and absence, and the size of the local undertaking.

Despite the difficulties of getting comparable information from different industries, the Acton Society Trust has secured three sets of data which are sufficiently alike to permit of certain broad comparisons. The most important statistical findings are summarized in the Table. In all three cases, attendance at work is inversely related to the size of the local undertaking. In the coal industry, correlations between various measures of attendance and size are of the order of 0.60 , in the industrial concern $0 \cdot 40$, and in the commercial concern around $\mathbf{0} \cdot 25$.

In one area of the National Coal Board where the average number employed in the collieries was 1,600 ,

* Size and Morale : A Preliminary Study of Attendance at Work in Large and Small Units. Acton Society Trust (1953). Pp. 44. Price 3s. 6d.
TABLE

ATTENDANCE AT WORK AND SIZE OF LOCAL UNDERTAKING

\begin{tabular}{|c|c|c|c|}
\hline $\begin{array}{c}\text { Index of } \\
\text { Attendance }\end{array}$ & Industry & $\begin{array}{l}\text { Unit and Period } \\
\text { of Observation }\end{array}$ & $\begin{array}{l}\text { Correlation } \\
\text { Coefficient }\end{array}$ \\
\hline $\begin{array}{l}\text { Proportion } \\
\text { bonus } \\
\text { worked }\end{array}$ shifts & Coal-mining & 18 pits for 3 & -0.67 \\
\hline Absence rates & $"$ & $\begin{array}{l}25 \text { wage districts } \\
\text { for } 12 \text { months }\end{array}$ & +0.60 \\
\hline $\begin{array}{l}\text { All absences of } \\
\text { hourly paid } \\
\text { men }\end{array}$ & $\begin{array}{l}\text { An industrial } \\
\text { concern }\end{array}$ & $\begin{array}{l}91 \text { factories for } \\
12 \text { months }\end{array}$ & +0.45 \\
\hline $\begin{array}{l}\text { All absences of } \\
\text { hourly paid } \\
\text { men due to } \\
\text { sickness }\end{array}$ & $"$ & " & +0.41 \\
\hline $\begin{array}{l}\text { Absences other } \\
\text { than those due } \\
\text { to certified } \\
\text { sickness }\end{array}$ & $"$ & $"$ & +0.33 \\
\hline All absences & $\begin{array}{l}\text { A commercial } \\
\text { concern }\end{array}$ & $\begin{array}{l}230 \text { retail stores } \\
\text { for } 12 \text { months }\end{array}$ & +0.24 \\
\hline
\end{tabular}

21,000 miners won as much coal as did 25,000 miners who worked in similar geological conditions in a neighbouring area, where the average number employed in the collieries was 2,500. In the East Midland coalfield it is estimated from the association between size and output that if the average size of colliery was doubled productivity would decline by about two-fifths.

In the coal-mining industry of Britain as a whole the accident rate increases steadily with the size of the pit; from 63.5 per 100,000 manshifts in pits employing fєwer than 50 men, to 166.6 in those employing more than 3,000. Among the factories of the industrial concern, the larger ones tended to have higher accident rates, and the duration of absence following accidents in them was longer.

Most of the accidents which occur at work are not directly due to the technical operations carried out. In the factories studied, only one-twentieth of the accidents were directly due to technical mishaps. In the collieries, it was the accidents that occurred on the surface and those due to stumbling which were most likely to increase with the size of the colliery, not those due to falls at the coal face. A detailed examination at one colliery of the daily variations in absences, and of the explanation given for these absences, showed that on Mondays, the day of the week on which most men were away from work, there was an increase in each category of explanation. Moreover, the relative increase in each category was similar. On Mondays there were more men who explained their absence as due to oversleeping than on other days of the week ; there were also more men whose 
absence was due to certified sickness and to having had accidents.

By the accumulation of such instances, a strong case is built up for treating the rates of absences, accidents, and the like, as the outward and visible signs of underlying processes connected with the structure and functioning of social groups.

These findings, and the results of similar inquiries, can be examined in relation to four sets of major variables: (1) the formal structure of the local undertaking, and the larger concern of which it is a part ; (2) the composition of the labour force; (3) the informal social organization among workers and within management; and (4) the nature of the local community in which the undertaking is situated. These major variables are all related one to another, and each of them consists of several components which are also interrelated.

\section{The Formal Structure of the Undertaking}

An undertaking which has grown into a larger organization has usually developed a complex internal structure. Whatever the actual methods of production used, they necessitate certain social relationships between workers and management, and also among the workers and within the management. In larger undertakings, actual work on production and the organization of production inevitably become sharply set apart from one another. The relations between those engaged on different tasks become more specific and impersonal. Communications have to be more formal and selective, and concentrated in fewer channels. Greater complexity of the methods of production and the consequent specialization within management create pressures towards greater departmental autonomy. The purpose of these departments, originally conceived as means for realizing the ends of the whole organization, become ends in themselves to be realized even at the expense of other departments, and thus eventually of the larger organization. The situation is a familiar one in the National Health Service and the social services generally.

The analysis by Trist and Bamforth (1951) of the "long-wall" method of coal-mining provides an excellent example of this process among workers actually engaged on production. The method, the one most commonly used in Britain, divides the work up into 24-hour cycles of production, each comprising three shifts. A new cycle can begin only when the previous one has been fully completed. Similarly, each shift can accomplish its tasks successfully only if the previous shift finished off its work properly. The different tasks to be done on each shift are related far more directly to some of those carried out by the preceding and succeeding shifts than to other tasks carried out on the same shift. For the most part, even those men who do the same work on the same shift are not organized in teams but remain aggregates of individuals working in parallel. In short, a method of working which necessitates highly coordinated tasks at the same time separates, physically and socially, the very workers who need to cooperate, for it is the social relations which arise where people work together, and the social controls inhering in these relations, which most effectively regulate the performance of common tasks (Homans, 1951).

It is possible, then, that underneath the social difficulties there is a conflict within the social organization of industry which is both fundamental and inevitable. The tendency towards increased specialization and minute sub-divisions of labour separates physically and socially the workers engaged on various tasks while increasing the interdependence of these tasks. The methods which are designed to simplify and standardize parts of an operation increase the complexity of the whole. The very arrangements which create the need for closer cooperation hamper and even prevent the development and maintenance of necessary social relationships.

Similar problems arise in supervision. Much of the work of actually organizing production and setting the pace, originally carried out by foremen, has passed to production engineers and rate-setting departments. The tasks of supervisors are becoming increasingly limited to those of routine supervision and of keeping production up to the levels specified by other departments-to "police-work" in fact. Such procedures may be satisfactory up to a point. The Acton Society Trust's report establishes the fact that in most of the National Coal Board's areas an increase in the proportion of supervisors to other workers was attended by a decline in the absence rates. In the commercial concern, where the span of control (that is, the number of workers per supervisor) was much narrower than in mining, there was no correlation between absence-rates and the proportion of supervisors to staff. The absence-rates of those N.C.B. areas which already had a comparatively narrow span of supervisory control did not decline when still more supervisors were employed. Moreover, measures to reduce the span of control at the lowest level of supervision introduce new difficulties. An increase in the number of supervisors at this level entails either an increase in the span of control at the next level, or an increase in the number of levels within the executive structure. A strike of the first-line supervisors at a large Yorkshire colliery suggests that this familiar dilemma of industrial administration is already having repercussions.

\section{Composition of the Labour Force}

Comparisons of absence-rates and labour turnover in different industries must take into account gross variations in the composition of the labour force. Generally speaking, skilled workers change their jobs less frequently than the semi-skilled and unskilled, men less often than women, older workers and those who have worked for longer periods in an undertaking less than younger workers and those who have worked for shorter periods (Social Survey SS 134, 1945-49 ; Long, 1951). Absences from work follow much the same trends except that the oldest workers are more often away than the younger and the middle-aged (Behrend, 1951).

The mining industry employs men almost exclusively, and has a comparatively stable labour force. To some extent this counteracts the disruptive tendencies of the 
long-wall method of mining, and enables some social relations with workmates to persist. Thus, what happens inside an undertaking may be more significant than what goes on outside. The commercial concern employs women for the most part and will have a constantly changing labour force. In this kind of situation workers are more likely to be affected by what happens outside the undertaking than by what happens inside it. Such factors partly account for some of the apparent discrepancies in the Trust's findings. The correlation of the absence-rate with size of undertaking was highest for the collieries and lowest for the chain stores; the correlation of absence-rates with the size of the town in which the store was located exceeded that between absence-rates and the size of the store itself. The corresponding correlation between size of undertaking and absence-rates was higher among those workers of the industrial concern who had staff grading and who, generally speaking, would be the older employees and those with longer service, than among those who did not have staff grading. Demographic considerations, then, can afford valuable clues to the internal structure of groups.

\section{Informal Social Organization}

It is now generally accepted that social groupings develop among people working together even though there may be little or no functional connexion between the tasks on which they are engaged (Moore, 1951). The persistence and solidarity of these groups are much affected by the formal structure of the undertaking, and such features of its labour force as the amount of labour turnover. In the more stable of such groupings, standards of expected behaviour and means of controlling departures from them become firmly established. Such norms may regulate not only output but the extent to which other rules laid down by the management are actually observed. It should not be supposed that the norms of informal groups always run counter to the aims of the management. In Britain, for instance, the " normal" working of the railways depends upon disregarding some of the official regulations; the entire system can be paralysed if the railwaymen decide to observe regulations meticulously and "work to rule".

Though sociologists have not yet produced satisfactory general propositions covering relations between formal structure and informal organization in industry, the available evidence is fairly consistent. It suggests that the informal social organization is more effective when the size and stability of the working group defined by the formal structure enable all the workers to be included in a single informal group, however much this may be further divided into sub-groups and cliques (Miller and Form, 1951). The Trust was able to show that pits working several seams simultaneously returned absence-rates and accident-rates which were significantly lower than those for other pits in the same area employing a similar number of men but working only a single seam. This is in line with the earlier findings of Marriott (1949) and of Hewitt and Parfit (1953). The former showed that in two engineering works output was inversely related to the size of the group engaged upon a particular set of tasks. The latter studied a hosiery factory which employed chiefly women, who worked in rooms of different sizes. Although those who worked side by side in the same room were not organized as a team or paid on this basis, absences for reasons other than certified sickness from the larger rooms were in significant excess of absences from the smaller rooms. Clearly, informal social organization must be considered as well as the formal structure of the undertaking.

\section{The Nature of the Local Community}

In the past, the nature and needs of local undertakings have determined the sites, shape, and size of many industrial towns and villages in Britain. Often they owned the houses in them and the very ground on which they stood. The local community may quite literally still live in the shadows of the undertaking for which it provides the labour force. In these circumstances it is inevitable that the social forces operating within the undertaking and those which operate outside it will markedly affect each other. Thus differences in the balance between the social forces inside and those outside the undertaking may partly explain observed differences in the correlations between various measures of absence. It is certainly pertinent that in the coal industry, where local undertaking and local community are still most closely connected, all measures of absence are correlated with one another and with the size of the undertaking; in the industrial concern there was no correlation between absence without leave and size. Many miners live among the men with whom they work ; social relations effective within the pit are often maintained outside it, and vice versa. Here, very possibly, the informal group regulates not only behaviour at work but whether or not men come to work at all. Among those who work in factories, offices, and shops, there is far less overlap between what happens at work and life outside. Especially in larger towns and cities people who work together are far less likely to mix with one another in their leisure time. It has already been pointed out that in the commercial concern, absence was, if anything, more closely associated with the size of the town than with the size of the store.

The study of the relations between the internal structure of the undertakings and the communities in which they are set poses many difficult problems of research method. Nevertheless, an examination of the other issues already touched upon eventually leads back to this problem, perhaps the most crucial in social inquiry today.

From time to time, the interests of distinct and separate disciplines converge. Absences from work due to accidents, certified sickness, and other causes, their incidence, and factors related to the ways in which they vary are of importance not only to economists, psychologists, and sociologists, but also to doctors, especially those practising industrial and social medicine. At the same time, procedures for studying these matters are not highly developed. Indeed, further research, so far from contributing to present practice, will probably begin by emphasizing its deficiencies. This is unlikely to 
cause alarm in medicine where advances in knowledge have frequently begun in this way.

Research of this type will lead to a general realization that behaviour at work is social behaviour and work itself a social activity. Exhortations about how people should behave addressed to people conceived of either as isolated individuals or as an undifferentiated mass are beside the point. People live and work in social groups of one kind or another and the individual rarely creates the norms of the groups to which he belongs. But the problems involved in studying these complex systems of social relations are immense, and the procedures for investigating them but little developed. It is a peculiar excellence of Size and Morale that it directs attention to issues which can be profitably studied with techniques already available.

\section{REFERENCES}

Behrend, H. (1951). Absence Under Full Employment, Birmingham. Hewitt, D., and Parfit, J. (1953). Occup. Psychol., 27, 38.

Homans, G. C. (1951). The Human Group. Routledge and Kegan Paul, London.

Long, J. R. (1951). Labour Turnover under Full Employment. Studies in Economics and Society. Monograph A 2. University of Birmingham.

Marriott, R. (1949). Occup. Psychol., 23, 47.

Mayo, E. (1949). The Social Problems of an Industrial Civilization. Routledge and Kegan Paul, London.

Miller, D. C., and Form, W. H. (1951). Industrial Sociology. Harper, New York.

Moore, W. E. (1951). Industrial Relations and the Social Order, rev. ed. Macmillan, New York.

Roethlisberger, F. J. (1942). Management and Morale. Harvard University Press, Cambridge, Mass.

-, and Dickson, W. J. (1939). Management and the Worker. Harvard University Press, Cambridge, Mass.

Social Survey SS 134. Labour Mobility in Great Britain, 1945-1949, by $\mathbf{G}$. Thomas.

Trist, E. L., and Bamforth, K. W. (1951). Hum. Relat., 4, 3.

\section{Third Conference of the British Occupational Hygiene Society}

The Society's third conference has been arranged for Monday, November 1, 1954, starting at 11 a.m. and will be held at the London School of Hygiene and Tropical Medicine, Keppel Street, London, W.C.1. (by kind permission of the Dean). The conference will be devoted to a discussion of radiation hazards in industry. The conference is open to non-members (on payment of the conference fee) as well as to members of the Society.

The Chair will be occupied by the President, Professor E. J. King, Professor of Chemical Pathology at the Postgraduate Medical School, University of London.

Four papers will be presented. There will be a short discussion after each paper. Abstracts of the papers will be sent to all those who have notified the Hon. Treasurer of their intention to be present.

The conference will be reported in the January, 1955 , issue of the Rritish Journal of Industrial Medicine.

\section{Programme}

11 a.m. Opening of the Conference by the President.

11.5 a.m. The Health of Workers Exposed to Ionizing Radiation, by A. S. McLean, M.B., Ch.B., D.I.H., Principal Medical Officer, Department of Atomic Energy.

12.5 p.m. Radiation Safety in the Industrial Group of the Department of Atomic Energy, by D. R. R. Fair, O.B.E., B.Sc., A.Inst.P., Head of the Health Physics Division, Department of Atomic Energy, Windscale Works, Sellafield.

1.5 p.m. Luncheon interval.

2.30 p.m. Protection against $X$ rays and Gamma rays in the Industrial Field, by W. Binks, M.Sc., F.Inst.P., Radiological Protection Service, Ministry of Health and Medical Research Council.

3.30 p.m. Safety Criteria in Atomic Energy, by F. R. Farmer, B.A., Assistant Director (Production), Department of Atomic Energy, Industrial Group Headquarters, Risley.

4.30 p.m. Adjournment for tea.

The Hon. Secretary is Peter C. G. Isaac, Public Health Engineering Laboratory, King's College, Newcastle-upon-Tyne. 